\title{
Pengaruh Kompensasi Terhadap Produktivitas Kerja Karyawan Pada PT. Alfabet Berkat Citrabuana
}

\author{
${ }^{1}$ Mohamad Duddy Dinantara, Della Oktaviani \\ Dosen Fakultas Ekonomi Universitas Pamulang \\ ${ }^{1}$ Email : dosen00818@unpam.ac.id
}

\begin{abstract}
ABSTRAK
Tujuan pada penelitian ini adalah untuk mengetahui pengaruh kompensasi terhadap produktivitas pada PT. Alfabet Berkat Citrabuana.

Metode yang digunakan adalah metode deskriptif dengan pendekatan asosiatif. Teknik sampling yang digunakan adalah proporsional random sampling menggunakan metode teknik sampling jenuh dengan sampel sebanyak 60 responden. Analisis data menggunakan analisis regresi, analisis koefisien korelasi, analisis koefisien determinasi dan uji hipotesis.

Hasil penelitian kompensasi pada PT. Alfabet Berkat Citrabuana dengan 10 pernyataan, memberikan jawaban yang bervariasi. Indikator gaji diperoleh skor sebesar 4,70, indikator insentif skor sebesar 3,85, indikator bonus skor 3,90, indikator upah skor sebesar 3,83, indikator premi skor 4,12, indikator pengobatan skor sebesar 3,91 sedangkan indikator asuransi skor sebesar 3,83. Secara keseluruhan skor rata-rata dari lima indikator termasuk pada rentang skala 3,404,19 dengan kriteria baik.

Produktivitas Kerja karyawan pada PT. Alfabet Berkat Citrabuana, responden, memberikan jawaban yang bervariasi. Indikator kemampuan skor sebesar 4,28, indikator meningkatkan hasil yang dicapai skor sebesar 3,90, indikator pengembangan diri rata-rata skor 3,93, indikator mutu skor rata-rata sebesar 3,72 sedangkan indikator efisiensi rata-rata skor sebesar 4,04. Secara keseluruhan skor rata-rata dari lima indikator termasuk pada rentang skala 3,404,19 dengan kriteria baik. Terdapat pengaruh positif dan signifikan kompensasi terhadap produktivitas kerja dengan kontribusi pengaruh sebesar 0,5041 atau $50,41 \%$ sedangkan sisanya sebesar $49,59 \%$ dipengaruhi faktor lain. Uji hipotesis diperoleh $\mathrm{t}$ hitung $>\mathrm{t}$ table atau $(7,728>2,002)$ dengan demikian $\mathrm{H} 0$ ditolak dan Ha diterima artinya terdapat pengaruh positif dan signifikan antara kompensasi terhadap produktivitas kerja karyawan.
\end{abstract}

\section{Kata Kunci : Kompensasi , Produktivitas Kerja}




\section{PENDAHULUAN}

\section{A. Latar Belakang Masalah}

Sumber daya manusia adalah mahluk sosial yang menjadi kekayaan utama bagi setiap organisasi, sumber daya manusia inilah yang menjadi pelaku utama dalam mencapai tujuan organisasi. Manusia merupakan unsur terpenting, karena unsur lain yang dimiliki oleh suatu organisasi seperti uang, materi, mesin-mesin, modal kerja, waktu, dan kekayaan lainnya hanya dapat memberi manfaat bagi organisasi jika manusia di dalam organisasi itu merupakan daya pembangunan dan perusak bagi organisasi. Oleh karena itu karyawan yang berkualitas, yaitu karyawan yang melaksanakan pekerjaannya kinerja yang tinggi, sangatlah dibutuhkan oleh organisasi untuk mencapai tujuan dan program pembangunan karena pada dasarnya keberhasilan organisasi secara keseluruhan adalah kontribusi dari hasil kerja karyawannya.

Karyawan adalah setiap orang yang bekerja dengan menjual tenaganya (fisik dan pikiran) kepada suatu perusahaan dan memperoleh balas jasa sesuai dengan peraturan dan perjanjian. Besarnya balas jasa teleh ditentukan dan diketahui sebelumnya, sehingga karyawan secara pasti mengetahui besarnya balas jasa/kompensasi yang akan diterimanya. Kompensasi inilah yang akan dipergunakan karyawan itu beserta keluarganya untuk memenuhi Kebutuhankebutuhannya. Besarnya kompensasi mencerminkan status, pengakuan, dan tingkat pemenuhan kebutuhan yang dinikmati oleh karyawan bersama keluarganya. Jika balas jasa yang diterima karyawan semakin besar berarti jabatannya semakin tinggi, statusnya semakin baik, dan pemenuhan kebutuhan yang dinikmatinya semakin banyak pula. Dengan demikian, kepuasan kerjanya juga semakin baik. Disinilah letak pentingnya kompensasi bagi karyawan sebagai seorang penjual tenaga (fisik dan pikiran).

Kompensasi merupakan pengeluaran dan biaya bagi perusahaan mengharapkan agar kompensasi yang dibayarkan memperoleh imbalan prestasi kerjan yang lebih besar dari karyawan. Jadi, nilai prestasi kerja karyawan harus lebih besar dari kompensasi yang dibayarkan perusahaan, supaya perusahaan mendapatkan laba dan kontinuitas perusahaan terjamin. Kompensasi bukan hanya penting bagi karayawan saja, melainkan penting juga bagi organisasi itu sendiri, karena program-program kompensasi adalah merupakan pencerminan upaya organisasi untuk mempertahankan sumber daya manusia. Bila organisasi tidak memperhatikan dengan baik tentang kompensasi bagi karyawannya, tidak mustahil organisasi itu lambat laun akan kehilangan sumber daya manusia yang berkualitas tinggi. Oleh karena itu kebijaksanaan tersebut diharapkan dan memuaskan kedua belah pihak, yaitu peningkatan kompensasi diharapkan akan meningakatkan kinerja karyawan. 
Pemberian kompensasi yang diberikan oleh PT. Alfabet Berkat Citrabuana belum optimal, dilihat dari penerimaan gaji pokok karyawan yang masih di bawah UMP (Upah Minimum Provinsi) kemudian dalam hal pemberian upah lembur dan bonus karyawan seringkali mengalami keterlambatan maka hal ini dapat menyebabkan menurunnya produktivitas karyawan. Selain upah, kompensasi dapat berupa penerimaan tidak langsung seperti peremi asuransi. Pemerintah mewajibkan BPJS Kesehatan sebagai asuransi kesehatan yang harus diikuti oleh semua perusahaan dan bersifat wajib untuk karyawan tanpa terkecuali. Namun pada PT. Alfabet Berkat Citrabuana keikutsertaan karyawan pada BPJS Kesehatan belum mencapai 100\%, kepesertaan BPJS belum mencapai $100 \%$ bahkan hngga 3 tahun berjalan. Hal ini menyebabkan masih ada karyawan yang tidak dapat berobat menggunakan BPJS Kesehatan. Tentunya hal ini akan berdampak pada kesehatan karyawan dimana mereka akan kesulitan berobat dan dapat menggangu produktivitas karyawan.

Produktivitas kerja sangat penting bagi setiap perusahaan, karena umur suatu perusahaan ditentukan dari produktivitas kerja karyawan yang dimiliki. Produktivitas kerja yang baik dapat dipengaruhi oleh beberapa faktor, salah satunya kompensasi. Produktivitas kerja adalah suatu perbandingan antara hasil keluaran dan masukan. Masukan sering dibatasi dengan tenaga kerja, sedangkan keluaran diukur dalam kesatuan fisik, bentuk, dan nilai. Perusahaan yang menyadari bahwa pentingnya kompensasi dalam meningkatkan produktivitas kerja akan lebih maju karena karyawan akan lebih merasa aman dalam melaksanakan pekerjaannya dan jauh dari kecelakaan kerja, mengenai produktivitas kerja karyawan pada PT. Alfabet Berkat Citrabuana. Pada tahun 2014 dengan jumlah karyawan 60 orang tingkat Rp.865.000.000,-, tahun berikutnya di 2015 jumlah karyawan 60 orang tingkat penjualan Rp. 957.000.000,-, tahun 2016 jumlah karyawan 60 tingkat penjualan Rp. 781.000.000,-, tahun 2017 jumlah karyawan 60 tingkat penjualan Rp. 810.000.000,-dan tahun 2018 jumlah karyawan 60 tingkat penjualan Rp. 668.000.000,-dapat dilihat dari pemaparan tersebut bahwa tingkat penjualan masih dibawah target pencapaian yaitu Rp.1.000.000.000 pertahun.

\section{B. Identifikasi Masalah}

Berdasarkan latar belakang masalah yang telah diuraikan diatas, maka dapat diindentifikasikan masalah sebagai berikut:

1. Pemberian upah tidak sesuai dengan UMP (Upah Minimum Provinsi)

2. Asuransi berupa BPJS Kesehatan belum maksimal

3. Produktivitas kerja karyawan menurun

4. Masih banyak karyawan yang kurang konsentrasi dalam 
bekerja sehingga target-target perusahaan tidak tercapai

\section{Rumusan Masalah}

Adapun

rumusan

masalahnya adalah:

1. Bagaimana kompensasi pada PT. Alfabet Berkat Citrabuana?
2. Bagaimana produktivitas kerja karyawan pada PT. Alfabet Berkat Citrabuana?

3. Seberapa besar pengaruh kompensasi terhadap produktivitas kerja karyawan pada PT. Alfabet Berkat Citrabuana?

\section{Kerangka Berpikir}

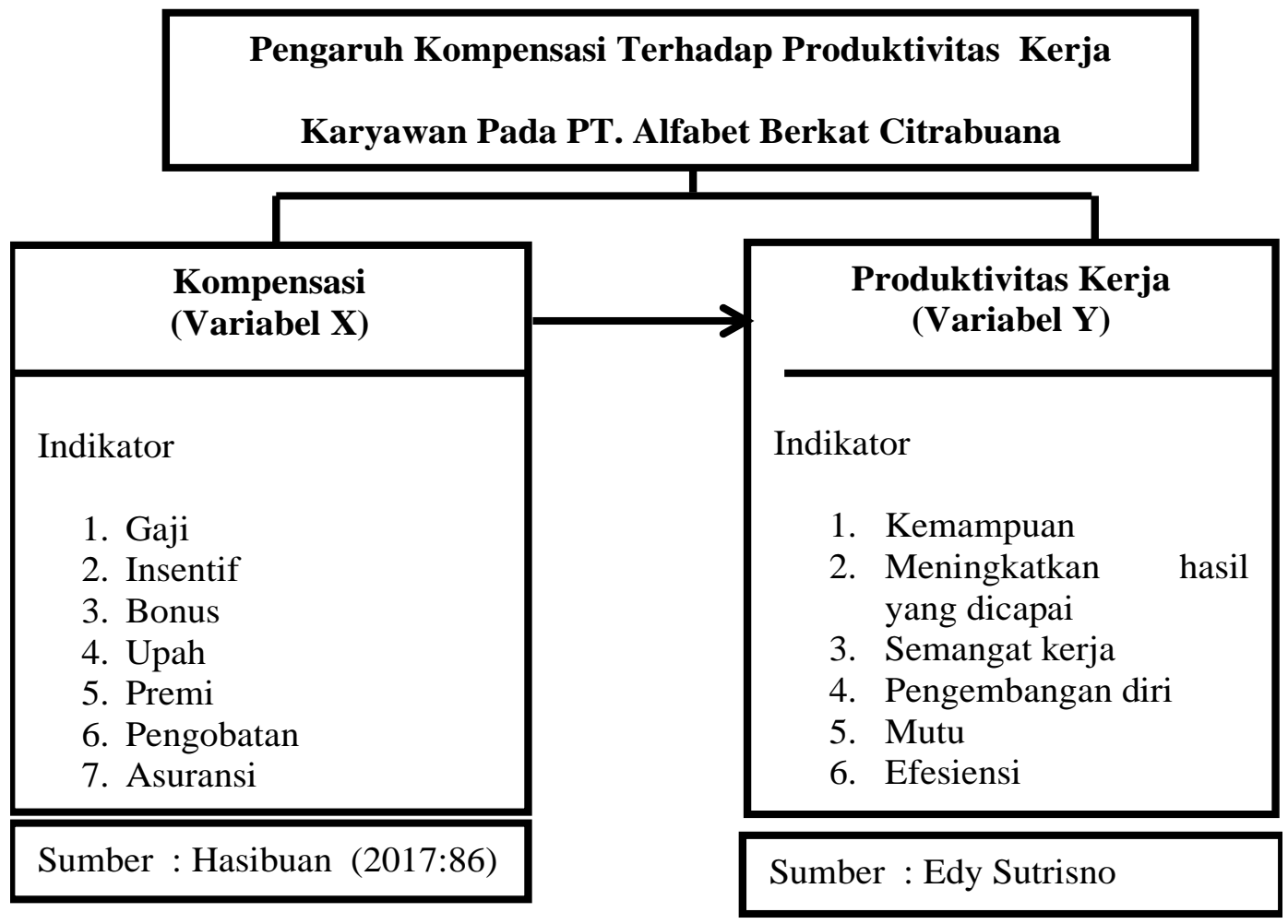

Gambar 1.1

Kerangka berfikir

\section{E. Hipotesis}

Ho $=0$ : Diduga tidak ada pengaruh yang positif dan signifikan Kompensasi terhadap Produktivitas kerja Karyawan Pada PT Alfabet Berkat Citrabuana.

$\mathrm{Ha} \neq 0$ : Diduga terdapat pengaruh yang positif dan signifikan Kompensasi terhadap Produktivitas kerja Karyawan Pada

PT Alfabet Berkat Citrabuana.

\section{TINJAUAN PUSTAKA}

\section{A. Kompensasi}

Menurut Sedarmayanti (2015:239) mengatakan bahwa "kompensasi adalah segala sesuatu yang di terima oleh karyawan 
sebagai balas jasa kerja mereka". Kompensasi yang berarti penghargaan atau balas jasa ternyata tidak hanya sekedar berbentuk upah atau gaji sebagai akibat dari pekerjaannya seseorang menjadi tenaga kerja atau karyawan suatu perusahaan. Menurut Sastrohadiwiriyo Dalam Buku Yuniarsih (2011:125) Pengertian kompensasi menurut Sastrohadiwiryo adalah imbalan saja atau balas jasa yang diberikan perusahaan kepada para tenaga kerja, karena para tenaga kerja tersebut telah memberikan sumbangan tenaga dan pikiran mereka demi kemajuan perusahaan guna mencapai tujuan yang ditetapkan.

Menurut Handoko Dalam Septawan (2014:5) Pengertian kompensasi menurut handoko adalah segala sesuatu yang diterima oleh pekerja sebagai balas jasa atas kerja mereka. Yani (2012: 139) Pengertian kompensasi menurut Yani adalah bentuk pembayaran dalam bentuk manfaat dan insentif untuk memotivasi karyawan agar produktivitas kerja semakin meningkat.

Dari beberapa definisi diatas, bahwa kompensasi merupakan hak yang harus diterima oleh karyawan dan kewajiban yang harus diberikan perusahaan atas tenaga kerja dan jasa yang diberikan pekerja kepada perusahaan sehingga perusahaan dapat mencapai tujuannya.

\section{B. Produktivitas}

Menurut Edy Sutrisno (2016:99) produktivitas kerja secara umum diartikan sebagai hubungan antara keluaran (barang- barang atau jasa) dengan masukan (tenaga kerja, bahan, uang). Produktivitas kerja adalah ukuran efesiensi produktif. Suatu perbandingan antara hasil keluaran dan masukan. Masukan sering dibatasi dengan tenaga kerja, sedangkan keluaran diukur dalam kesatuan fisik, bentuk dan nilai.

Menurut Malayu S.P Hasibuan (2014:94) menyatakan bahwa produktivitas kerja adalah perbandingan antara output dengan input, dimana output-nya harus mempunyai nilai tambah dan tekhnik pengerjaan yang lebih baik.

Menurut Indah Puji Hartatik (2014) produtivitas kerja adalah kemampuan menghasilkan barang dan jasa dari berbagai sumber daya atau faktor produksi yang digunakan untuk meningkatkan kualitas dan kuantitas pekerjaan yang dihasilkan dalam suatu perusahaan.

Menurut Siagian (2012) adalah Produktivitas kerja kemampuan menghasilkan barang/jasa dari berbagai sumber daya dan kemampuan yang dimiliki oleh setiap pekerja/karyawan. Secara umum, produktivitas dapat diartikan sebagai kemampuan meningkatkan hasil kerja karyawan yang ditinjau dari sumber daya yang dimiliki oleh setiap masing-masing individu.

\section{METODE PENELITIAN}

Penelitian ini dilakukan pada PT. Alfabet Berkat Citrabuana. Jalan Kebon Sirih No. 63. Kelurahan Kebon Sirih . Kecamatan Menteng. Kota Jakarta Pusat.. Jenis penelitian 
ini adalah deskriptif kuantitatif, populasi karyawan yang berjumlah 60 karyawan.teknik pengambilan sample menggunakan sample jenuh yaitu seluruh populasi dijadikan sampel

Metode pengumpulan data menggunakan data primer yaitu observasi dan penyebaran kuesioner serta data sekunder yaitu dokumentasi dan studi kepustakaan, uji instrumen penelitian menggunakan uji validitas dan uji reliabilitas, metode analisis data menggunakan analisis deskriptif, adapun tahapan analisis yang dilakukan adalah analisis regresi linier sederhana analisis koefisien korelasi (R), analisis koefisien determinasi ( $R$ Square), pengujian hipotesis.

\section{HASIL PENELITIAN}

\section{A. Uji Instrumen}

\section{Uji Validitas Instrumen.}

Tabel 4.1

Hasil Uji Validitas

\begin{tabular}{|c|c|c|c|c|}
\hline $\begin{array}{c}\text { Item } \\
\text { Kuesioner }\end{array}$ & $\begin{array}{c}\mathrm{r} \text { hitung } \\
\text { Kompensasi }\end{array}$ & $\begin{array}{c}\mathrm{r} \text { hitung } \\
\text { Produktivitas }\end{array}$ & $\mathrm{r}$ tabel & Keputusan \\
\hline 1. & 0,537 & 0,440 & 0,254 & Valid \\
\hline 2. & 0,280 & 0,669 & 0,254 & Valid \\
\hline 3. & 0,528 & 0,594 & 0,254 & Valid \\
\hline 4. & 0,321 & 0,448 & 0,254 & Valid \\
\hline 5. & 0,290 & 0,494 & 0,254 & Valid \\
\hline 6. & 0,313 & 0,589 & 0,254 & Valid \\
\hline 7. & 0,260 & 0,488 & 0,254 & Valid \\
\hline 8. & 0,615 & 0,758 & 0,254 & Valid \\
\hline 9. & 0,425 & 0,339 & 0,254 & Valid \\
\hline 10. & 0,635 & 0,483 & 0,254 & Valid \\
\hline
\end{tabular}

Sumber: Data Primer diolah.

Berdasarkan data tabel di atasdiperoleh nilai $r$ hitung $>r$ tabel 0.254, dengan demikian maka semua item kuesioner dinyatakan valid. Untuk itu kuesioner yang digunakan layak untuk diolah sebagai data penelitian.

2. Uji Reliabilitas Instrumen.

Tabel 4.2

Hasil Uji Reliabilitas

Variabel Independen dan Dependen

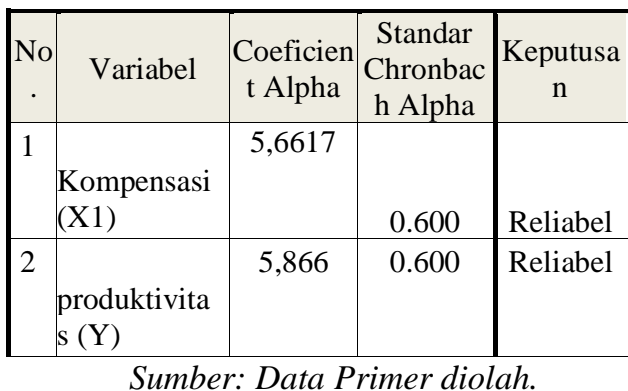

Berdasarkan hasil pengujian pada tabel di atas, menunjukkan bahwa masingmasing variabel memiliki nilai coeficien Alpha lebih besar dari Chronbath Alpha 0,600. 
B. Uji Statistik

\section{Koefisien Korelasi}

$r_{x y}$

$=\frac{n(\Sigma x y)-(\Sigma x) \cdot(\Sigma y)}{\sqrt{n \cdot \Sigma x^{2}}-(\Sigma x)^{2} \cdot \sqrt{\left(n \cdot \Sigma y^{2}-(\Sigma y)^{2}\right.}}$

$\mathrm{b}=\frac{33420}{37040}$

$\mathrm{b}=0,902$

$a=\frac{\Sigma y-b \Sigma x}{n}$

$a=\frac{2397-(0,902)(2360)}{60}$

$a=\frac{268,28}{60}$

$a=4,471$

$\hat{\mathrm{y}}=\mathrm{a}+\mathrm{bx}$

$\hat{y}=4,471+0,902(X)$

\section{Analisis}

Determinasi ( $R$ Square).

$\mathrm{KD}=\boldsymbol{r}^{2} \times 100 \%$

$=(0,71)^{2} \times 100 \%$

$=0,5041 \times 100 \%$

$=50,41 \%$

Nilai

koefisien

determinasi tersebut diatas menunjukan bahwa

Kompensasi memberikan kontribusi sebesar 50,41\% sedangkan selebihnya yaitu $49,59 \%$ dipengaruhi oleh faktor lain seperti motivasi, disiplin, kinerja dan lain - lain.

\section{Pengujian Hipotesis.}

$\mathrm{t}=\frac{r \sqrt{n-2}}{\sqrt{1-r^{2}}}$

$\mathrm{t}=\frac{5,4102}{0,70}$

$\mathrm{t}=7,728$

Hasil thitung tersebut selanjutnya dibandingkan dengan hasil $t_{\text {tabel. Untuk }}$ kesalahan 5\% dan dk : n-2 $=60$ $-2=58$, maka diperoleh $\mathrm{t}_{\text {tabel }}$ $(2,002)$. Jadi dari hasil perhitungan uji hipotesis di atas maka dapat dilihat bahwa, $t_{\text {hitung }}>t_{\text {tabel }}$ atau 7,728>2,002 maka menunjukan hasilyang signifikan. Atau dengan kata lain $t_{\text {hitung }}>\mathrm{t}_{\text {tabel}}$, maka $\mathrm{H}_{\mathrm{a}}$ diterima $\mathrm{H}_{\mathrm{o}}$ ditolak, yang berarti bahwa terdapat pengaruh yang signifikan antara Kompensasi terhadap Produktivitas Kerja karyawan PT. Alfabet Berkat Citrabuana.

\section{KESIMPULAN DAN SARAN}

\section{A. Kesimpulan}

1. Pelaksanaan Kompensasi yang diterapkan pada PT. Alfabet Berkat Citrabuana masuk kategori baik, hal ini dibuktikan berdasarkan yang menjawab sangat setuju (SS) sebesar $26,83 \%$ dan setuju (S) sebesar $48,33 \% \quad(\mathrm{SS}+\mathrm{S}=$ $26,83 \%+48,33 \%=75,17 \%)$. Jika dilihat pada indikator gaji sebesar $70 \%$ atau 42 responden setuju jika gaji yang mereka terima telah dapat memenuhi kebutuhan fisik seperti sandang, pangan dan papan).

2. Produktivitas Kerja karyawan pada PT. Alfabet Berkat Citrabuana masuk kategori baik. Hal ini dibuktikan berdasarkan yang menjawab sangat setuju (SS) sebesar $27,83 \%$ dan setuju (S) sebesar $47,67 \% \quad(\mathrm{SS}+\mathrm{S}=$ $27,83 \%+47,67 \%=75,5 \%)$, dan untuk indikator total terbesar terdapat pada indikator kemampuan sebesar 58 responden menjawab sangat 
setuju. Karyawan terampil dalam melaksanakan pekerjaan sesuai dengan tugas \& fungsi dan tepat waktu dalam menyelesaikan pekerjaannya untuk mencapai tujuan perusahaan.

3. Dari hasil perhitungan menggunakan analisa koefisien korelasi dapat diketahui bahwa antara Kompensasi dan Produktivitas Kerja karyawan mempunyai hubungan yang kuat yaitu 0,714 . Sedangkan kontribusi variabel $\mathrm{X}$ (Kompensasi) terhadap variabel Y (Produktivitas Kerja Karyawan) dapat dijelaskan dalam uji koefisien determinasi yaitu sebesar $50,41 \%$ dan sisanya $49,59 \%$ dipengaruhi oleh faktor lain. Lalu besarnya pegaruh Kompensasi terhadap Produktivitas Kerja Karyawan didapat nilai taksiran $b=0,902$ dan apabila tidak ada kegiatan pada varibel $\mathrm{X}$ (Kompensasi), maka variabel Y (Produktivitas Kerja Karyawan) masih ada sebesar $\mathrm{a}=4,471$. Selanjutnya dalam hasil pengujian hipotesis menunjukan adanya pengaruh Kompensasi terhadap kinerja pada PT. Alfabet Berkat Citrabuana, hal ini didasari dalam uji hipotesis yang dapat disimpulkan $t_{\text {hitung }} \geq t_{\text {tabel }}$ dengan nilai $7,728 \geq 2,002$ maka dalam hal ini Ho ditolak dan $\mathrm{Ha}$ diterima, dan terdapat pengaruh yang signifikan antara Kompensasi terhadap Produktivitas Kerja Karyawan.

\section{B. Saran}
1. Perusahaan harus dapat meningkatkan

karyawan dalam kepesertaaan asuransi seperti yang diwajibkan oleh pemerintah yaitu BPJS Kesehatan. Sehingga karyawan mempunyai ketenangan ketika mereka sakit dapat berobat tanpa memerlukan biaya. Hal ini akan berpengaruh terhadap produktivitas kerja karyawan dikarenakan terdapat jaminan kesehatasan atas dirinya.

2. Perusahaan harus dapat meningkatkan mutu pekerjaan setiap karyawan dengan memperhatikan karyawan mana yang kesulitan dalam memberikan mutu pekerjaan yang baik, dan memberikan pelatihan atau konseling atas pekerjaannya agar karyawan dapat meningkatkan mutu pekerjaan yang ia hasilkan.

\section{DAFTAR PUSTAKA}

Anton Mulyono Aziz dan Maya Irjayanti. 2014. Manajemen. Bandung: Mardika Group.

Arikunto, Suharsimi. 2014. Prosedur Penelitian Suatu Pendekatan Praktik. Jakarta : Rineka Cipta.

Dessler, Gary. 2010 . Manajemen Sumber Daya Manusia (edisi kesepuluh). Jakarta Barat: PT Indeks.

Gaol, CHR. Jimmy L. 2014. A to Z Human Capital (Manajemen Sumber Daya Manusia) Konsep, Teori, dan Pengembangan dalam Konteks Organisasi Publik dan Bisnis. Jakarta: PT. Gramedia Widiasarana.

Ghozali, Imam. 2017. Aplikasi Analisis Multivariete Dengan Program (IBM SPSS). Edisi 8. 
Semarang : Badan Penerbit Universitas Diponegoro.

Handoko, T. Hani. 2017. Manajemen. Edisi ke 2, Yogyakarta BFPEYogyakarta.

Hartatik, Indah Puji. 2014. Buku Praktis Mengembangkan SDM. Yogyakarta: Laksana.

Hasibuan, Melayu S.P. 2017. Manajemen sumber daya manusia. Bandung: Remaja Rosdakarya.

Mangkunegara, AA Anwar Prabu. 2016. Evaluasi Kinerja SDM. Bandung: PT. Refika Aditama. Sarwono, Jonathan. 2016. Metode Penelitian Kuantitatif dan Kualitatif. Yogyakarta : Graha Ilmu.

Sedarmayanti. 2015. Manajemen Sumber Daya Manusia Bandung: PT.Refika Aditama.

Septawan. 2014. Manajemen Personalia dan Sumber Daya Manusia. Yogyakarta : BPFE, Pers.

Siagian, Sondang P. 2012. Manajemen Sumber Daya Manusia. Jakarta: PT. Rineka Cipta.

Sinungan, Muchdarsyah. 2014. Produktivitas Apa dan Bagaimana. Bandung:

Stres. Cetakan ke-1. Yogyakarta : Tugu Publisher.

Sugiyono. 2016. Metode Penelitian Kuantitatif, Kualitatif, dan R\&D. Bandung: Penerbit Alfabeta.

Sulastri, Lilis. 2014. Manajemen Sebuah Pengantar Sejarah,
Tokoh, Teori, dan Praktik. Bandung: LGM - LaGood's Publishing.

Sunarsi, D. (2018). Pengaruh Rekrutmen, Seleksi Dan Pelatihan Terhadap Produktivitas Kerja Karyawan. Kreatif: Jurnal Ilmiah Prodi Manajemen Universitas Pamulang, 6(1), 14-31.

Sunarsi, D. (2019). Pengaruh Kompensasi, Komunikasi Dan Stress Kerja Terhadap Prestasi Kerja Karyawan Pada PT Catur Putra Jaya Kota Depok-Jawa Barat. JIMF (Jurnal Ilmiah Manajemen Forkamma), 1(2).

Supangat, Andi. 2011. Statistik Dalam Kajian Deskriptif, Inferensi, dan Nonparametrik. Jakarta : Kencana Prenada Media Group.

Sutrisno, Edy. 2016. Manajemen Sumber Daya Manusia, Cetakan ke delapan.. Jakarta: Kencana Prenada Media Group. Triswanto, Sugeng. 2011. Trik Menulis Skripsi dan Menghadapi Presentasi Bebas

Triton, PB. 2009. Mengelola Sumber Daya Manusia, Cetakan Pertama. Yogyakarta: Penerbit Oryza

Yani, M. 2012. Manajemen Sumber Daya Manusia. Jakarta: Mitra Wacana Media.

Yunarsih, Tjutju. Dan Surwanto. 2011. Manajemen Sumber Daya Manusia 